\title{
Rational modifications, synthesis and biological evaluation of new potential antivirals for RSV designed to target the M2-1 protein
}

Salvatore Ferla ${ }^{\mathrm{a}^{*}}$, Roberto Manganaro ${ }^{\mathrm{a}}$, Sara Benato ${ }^{\mathrm{a}}$, Jasmine Paulissen ${ }^{\mathrm{b}}$, Johan Neyts ${ }^{\mathrm{b}}$, Dirk Jochmans ${ }^{\mathrm{b}}$, Andrea Brancale $^{\mathrm{a}}$, Marcella Bassetto ${ }^{\mathrm{a}, \mathrm{c}}$

${ }^{a}$ Cardiff School of Pharmacy and Pharmaceutical Sciences, Cardiff, King Edward VII Avenue, Cardiff, CF103NB, UK

${ }^{b}$ KU Leuven - Department of Microbiology, Immunology and Transplantation, Rega Institute, Laboratory of Virology and Chemotherapy, Leuven, Belgium.

'Department of Chemistry, Swansea University, Swansea, UK

*Corresponding author

E-mail address: ferlas1@cardiff.ac.uk (Dr. S.Ferla)

\section{Highlights}

- Rational modifications on a zinc-ejecting anti-RSV scaffold.

- Synthesis of novel analogues to explore antiviral SARs.

- New inhibitors of RSV replication identified.

- Molecular dynamics and molecular docking studies on the RSV M2-1 protein.

\begin{abstract}
Respiratory syncytial virus (RSV) is the main cause of lower respiratory tract diseases in infants and young children, with potentially serious and fatal consequences associated with severe infections. Despite extensive research efforts invested in the identification of therapeutic measures, no vaccine is currently available, while treatment options are limited to ribavirin and palivizumab, which both present significant limitations. While clinical and pre-clinical candidates mainly target the viral fusion, the nucleocapsid protein or the viral polymerase, our focus has been the identification of new antiviral compounds targeting the viral M2-1 protein, thanks to the presence of a zinc-ejecting group in their chemical structure. Starting from an anti-RSV hit we had previously identified with an in silico structure-based approach, we have designed, synthesised and evaluated a new series of dithiocarbamate analogues, with which we have explored the antiviral activity of this scaffold. The findings presented in this work may provide the basis for the identification of a new antiviral lead to treat RSV infections.
\end{abstract}

\section{Introduction}

Respiratory syncytial virus (RSV), a paramyxovirus, ${ }^{1}$ is the major responsible for acute lower respiratory tract infections in infants, children, immunocompromised patients, and elderly populations. ${ }^{2}$ Severe infections with this virus are often culminating in bronchiolitis and pneumonia, with potentially fatal consequences: ${ }^{3} \mathrm{RSV}$ is estimated to cause between 66000 and 199000 deaths every year in children under the age of five. ${ }^{4}$ Despite the fact that extensive 
research efforts have been dedicated to elucidate epidemiology, diagnosis and prevention/treatment since its discovery in 1956, no vaccine is currently available for this virus. ${ }^{5}$ Two antiviral drugs are approved by the FDA to treat or prevent serious RSV infections: ribavirin, a guanosine analogue with a broad-spectrum antiviral activity approved for treatment in aerosolic form, ${ }^{6}$ and palivizumab, a humanised monoclonal antibody with strong RSVneutralising ability, which can be used for prophylactic purposes. ${ }^{7}$ Nonetheless, ribavirin is non-specific for RSV, therefore not highly efficacious, and associated with toxicity issues and high costs, ${ }^{8}$ while the use of palivizumab is limited to high-risk populations due to its elevated cost. ${ }^{9}$ Different additional strategies to treat or prevent RSV infections are currently under clinical evaluation, including recombinant antibodies, nanobodies and small molecules targeting the viral life cycle. ${ }^{10}$ The most explored mechanism of action with small-molecule antiviral candidates is the inhibition of RSV fusion, which accounts for different agents in phase II clinical trials. ${ }^{11}$ Other candidates in clinical development include inhibitors of the viral nucleoprotein and inhibitors of the viral polymerase, which accounts for one nucleoside analogue, ALS-008176, in clinical evaluation, and various nucleoside and non-nucleoside inhibitors currently at different stages of pre-clinical investigations. ${ }^{10-11}$ Despite these advances, the development of safe and effective treatment options for RSV infections still represents an unmet medical need.

RSV is classified into two main groups, RSV-A and RSV-B, according to the antigenic sequence of the viral attachment glycoprotein, the G protein. ${ }^{12}$ Among the proteins encoded in RSV non-segmented, single-stranded, negative-sense RNA genome, the matrix protein M2-1 is an essential transcription anti-termination co-factor of the viral polymerase, ${ }^{13}$ and currently represents an underexploited target in the search for anti-RSV agents, with no candidate in preclinical or clinical development. The M2-1 protein is functional in a tetrameric form, ${ }^{14}$ and contains a zinc-binding domain (ZBD), whose proper functionality in coordinating a zinc ion co-factor is crucial for the enzyme activity. ${ }^{15}$ The zinc-binding activity of the M2-1 protein has been proven essential for viral replication and pathogenesis in vivo for related pneumoviruses, ${ }^{16}$ rendering its inhibition a promising strategy for developing new antivirals against RSV. In this context, one appealing approach to inhibit zinc-binding enzymes is represented by metal chelation with zinc-ejecting compounds, as is the case for example of zinc-ejecting HIV nucleocapsid inhibitors, some of which have reached phase II clinical trials for the treatment of AIDS. ${ }^{17}$ Starting from the identification of zinc-chelating small-molecule aldrithiol, AT-2, as inactivator of RSV at millimolar concentrations, ${ }^{18}$ and thanks to the availability of crystal structures of RSV M2-1 protein complexes, ${ }^{19-20}$ we have previously applied a structure-based 
drug design approach to this protein, which guided the synthesis of different new structural scaffolds. ${ }^{21}$ These novel small-molecules were characterised by the presence of a central zincejecting chemical group, functionalised with different lateral substituents to interact with the protein sub-sites surrounding the ZBD. Among these structures, we had identified a new dithiocarbamate scaffold (compound 1 in Figure 1), which inhibited RSV replication in vitro with an $\mathrm{EC}_{50}$ in the low micromolar range, without causing significant cytotoxicity. Aiming at further exploring the anti-RSV activity of this compound, the present study focusses on the design, synthesis and evaluation of a preliminary series of structural derivatives of $\mathbf{1}$. Herein we describe the identification of new potential anti-RSV agents with antiviral $\mathrm{EC}_{50}$ values in the low micromolar range, and the evaluation of their predicted binding to RSV M2-1 protein with a series of molecular dynamics and molecular docking simulations.<smiles>c1ccc(SSc2ccccn2)nc1</smiles>

AT-2

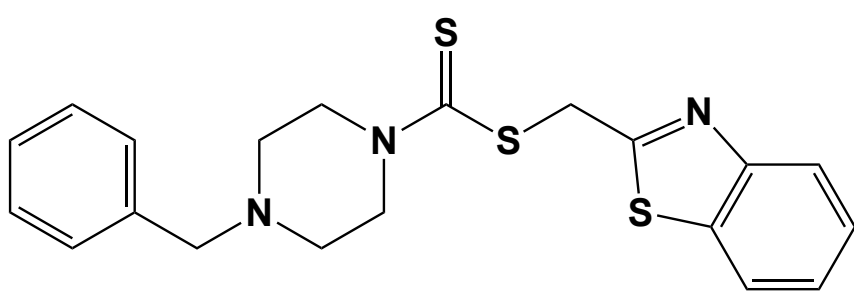

1

Figure 1: Chemical structure of aldrithiol (AT-2) and hit 1.

\section{Results and Discussion}

In this manuscript, in an effort to further improve the RSV replication inhibitory activity and to study the structure-activity relationships with new derivatives of our initial hit $\mathbf{1}$, we focussed our attention on introducing various electron-donating (EDG)/ electron-withdrawing (EWG) groups at different positions of the phenyl ring, and on replacing the original methylene bridge between the piperazine central core and the phenyl ring itself (Figure 2). The dithiocarbamate group, which is fundamental for its zinc-ejecting properties, the piperazine ring and the benzothiazole system, which in our pervious work were both found to be essential for the antiviral activity of $\mathbf{1}$, were kept unchanged, while their additional structural modifications is the focus of present investigations. 


\section{Insertion of various EDGs \\ or EWGs at different \\ positions}

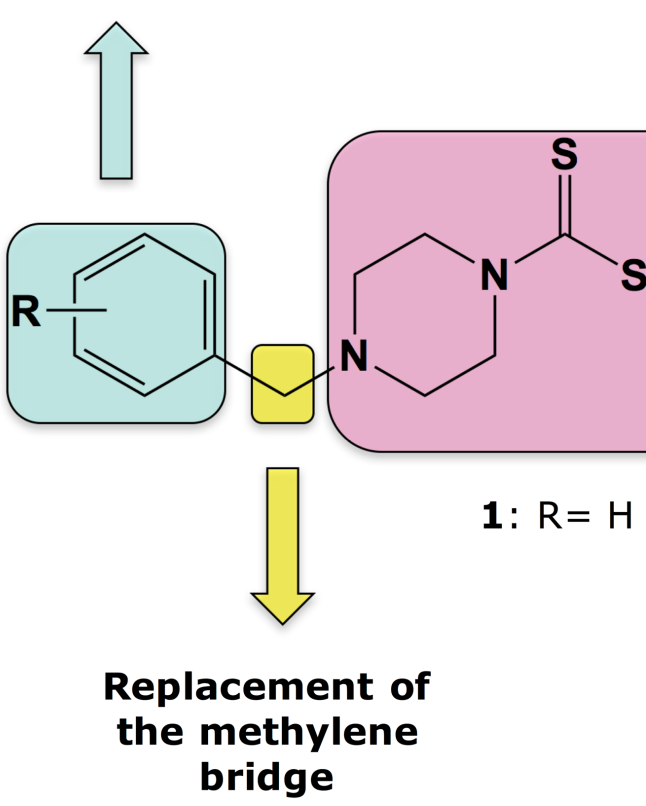

Figure 2: Planned structural modifications on the scaffold of hit 1.

\subsection{Chemistry}

The newly designed derivatives were prepared following Scheme 1, which has been obtained after several optimisations of reactions and routes. 2-Chloromethyl benzothiazole (5) was prepared in two steps modifying a previously reported procedure for the preparation of benzothiazinone compounds, by reacting 2-aminothiophenol (2) with chloroacetic acid (3), in dichloromethane (DCM) for $24 \mathrm{~h}$, in the absence of any base. ${ }^{22,23}$ The isolated amide salt 4 was then cyclised in acetonitrile $\left(\mathrm{CH}_{3} \mathrm{CN}\right)$ at reflux for $72 \mathrm{~h}$, giving the desired product in a better yield in comparison to a one-step synthesis method performed in parallel, in which intermediate amid salt $\mathbf{4}$ was the major product, with the desired compound obtained in a very low yield (6 \%). ${ }^{24}$ Benzyl piperazine derivatives (22-36) were obtained in good yields by reacting the corresponding commercially available benzyl chloride (7-21) with a large excess of piperazine (6), in order to avoid a double nucleophilic attack and the formation of a disubstituted piperazine molecule. ${ }^{25,26,27}$ Piperazine derivatives (34-36), in which the methylene linker has been replaced, were prepared exploiting different reagents and conditions in order to obtain the desired product in a good yield after column chromatography purification. ${ }^{25,28,29}$ 
Phenyl-piperazine 37 was purchased. Preparation of the final dithiocarbamate compounds 3846 was achieved through a nucleophilic displacement according to a reported one-step reaction, ${ }^{30}$ in which benzyl piperazine derivatives (22-30) and carbon disulfide were reacted in dimethylformamide (DMF), in the presence of sodium methoxyde $(\mathrm{NaOMe})$ at $0{ }^{\circ} \mathrm{C}$, followed by the addition of 5 to give the desired product. Final compounds 47-53 were obtained following a different two-step reaction, in which piperazine derivatives 31-37 and a large excess of carbon disulfide were reacted for $2 \mathrm{~h}$ in a strong basic ethanolic solution of potassium hydroxide $(\mathrm{KOH})$, forming dithiocarbamate salts $31 \mathbf{a - 3 7} \mathbf{a}^{31,32}$ The salts, recovered by filtration, were then reacted with 5 for $24 \mathrm{~h}$ using methanol $(\mathrm{MeOH})$ as solvent and triethylamine $\left(\mathrm{Et}_{3} \mathrm{~N}\right)$ as base, to afford the final products 47-53. Although both methods produced a similar range of final yields, the use of $\mathrm{EtOH}$ or $\mathrm{MeOH}$ as solvent instead of DMF and the absence of formation of side products, which makes the reaction purification much easier, suggested that the 2-step reaction was the most efficient procedure to follow.

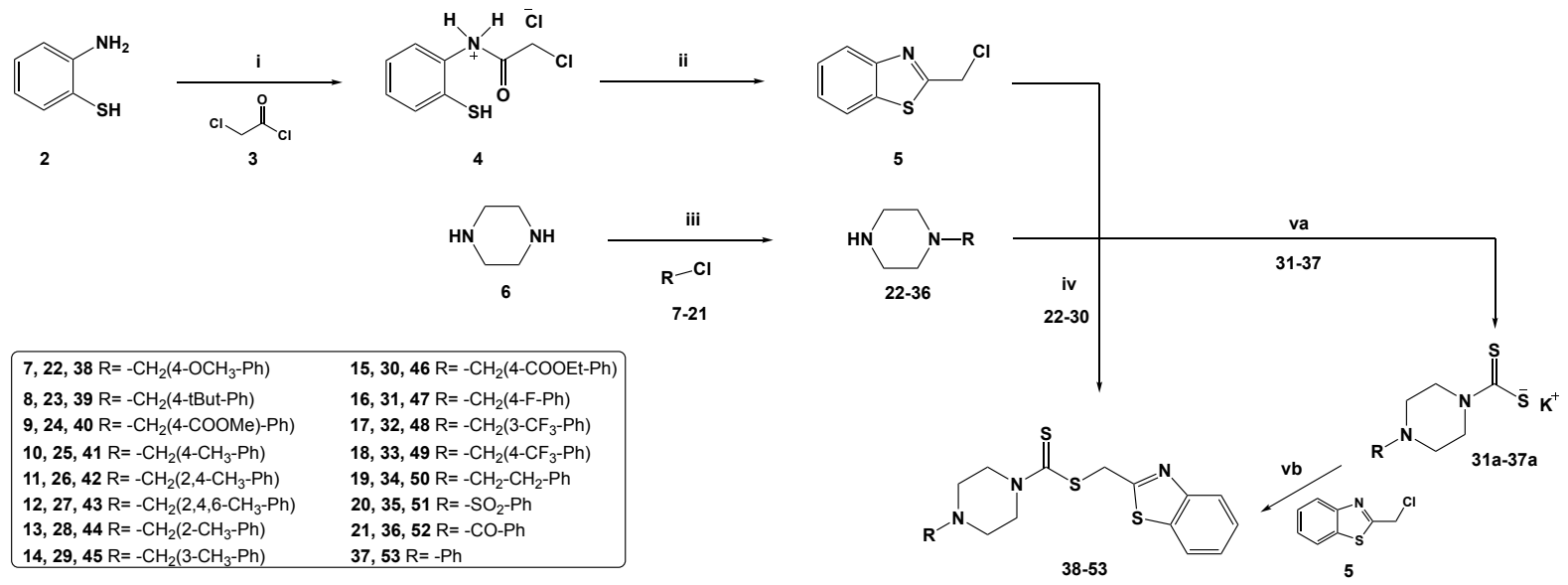

Scheme 1: Reagents and conditions: (i). DCM, r.t.,24h; (ii). $\mathrm{CH}_{3} \mathrm{CN}$, reflux, 72h, 59\%; (iii). THF, reflux, 4h for 22-33, 49$88 \%$, OR THF, reflux, $48 \mathrm{~h}$ for $34,72 \%$, OR DCM, $0^{\circ} \mathrm{C}, 30 \mathrm{~min}$. for $35,84 \%$, OR EtOH, r.t., $5 \mathrm{~h}$ for 36, 75\%; (iv). $\mathrm{CS}_{2}, \mathrm{NaOMe}$, $\mathrm{DMF} 0^{\circ} \mathrm{C} 30 \mathrm{~min}$, then o.n. for 38-46, 38-76\%; (v). a) $\mathrm{CS}_{2}, \mathrm{KOH}$, EtOH $0^{\circ} \mathrm{C}$ then r.t., $2 \mathrm{~h}$; b) $\mathrm{Et}_{3} \mathrm{~N}$, $\mathrm{MeOH}$, r.r., 24h for 47-53, $40-56 \%$.

\subsection{Antiviral evaluation}

All the newly synthetised compounds were evaluated for their potential antiviral activity in a cytophatic effect (CPE)-based in vitro assay in HEp-2 cells, in which the protective effect of the tested compounds against the virus-induced CPE was measured. Two different viral RSV strains, RSV-A and RSV-B, were used. Cells were treated with eight different concentrations 
(0.7-100 $\mu \mathrm{M})$ of the potential RSV inhibitors. The nucleoside viral polymerase inhibitor ALS8112 was used as positive control. ${ }^{33}$

Compound cytotoxicity $\left(\mathrm{CC}_{50}\right)$ was also determined using uninfected Hep-2 cells in a MTS assay. Results are reported in Table 1.

The activity of initial hit $\mathbf{1}$ is consistent with previously reported data, ${ }^{21}$ showing an antiviral effect in the low $\mu \mathrm{M}$ range against both viral strains. Insertion of an electron donating substituent in the para position of the phenyl ring, such as a mehtoxy (38), methyl (41) and $t$ butyl (39) group, seems to be associated with antiviral activity retention against strain B-RSV, having $\mathrm{EC}_{50}$ values similar to $\mathbf{1}$. On the contrary, these compounds show a different effect against strain A, giving a slightly less potent and more variable activity profile. The same effect against strain B is obtained when electron withdrawing groups, such as a methyl (40), a ethylcarboxylic ester (46), a trifluoromethyl (49) and a fluorine (47) in the para position. Notably, while 40 and 46 are characterised by a reduction of antiviral effect against strain A, derivatives 47 and 49 present similar EC $_{50}$ values against both strains. In general, these results indicate that the para position of the phenyl ring can be substituted without affecting antiviral activity. Importantly, the possibility to insert a fluorine atom or a trifluoromethyl group into the phenyl ring without impairing the biological activity could be used as means to exploit the established potential of fluorine atoms in enhancing the pharmacological profile and drug-like physicochemical properties of molecules with pharmacological activities, for the potential future development of this class of compounds. ${ }^{34}$ The presence of a substituent in meta position of the phenyl ring $(\mathbf{4 5}, \mathbf{4 8})$, regardless its EDG/EWG nature, is associated with a retained antiviral effect, with $\mathbf{4 8}$ having an equivalent $\mathrm{EC}_{50}$ value against strain $\mathrm{A}$ and $\mathrm{B}$, while the introduction of a methyl group in ortho (44) is correlated with a reduction of activity, indicating that there is enough space on the binding pocket to accommodate a phenyl ring differently substituted in meta or in para position, but not in ortho position.

Introduction of a second methyl group at the ortho position of 41 (42) is associated with a reduction of activity against strain $B$, while it seems not to affect antiviral activity against strain A. A more consistent result against the two strains is obtained inserting a third methyl group in ortho (43), which is associated with an almost 5-fold reduction in activity in both cases.

Extension of the methylene bridge to an ethyl linker (50) or its replacement with a $-\mathrm{SO}_{2}-(\mathbf{5 1})$ slightly affects antiviral activity, whereas a -CO- (52) linker led to a more marked drop of activity against the two strains. The reduction in activity could be either caused by the different polarity of the new linker, or by the different geometry conferred to the molecule. Interestingly, 53, in which the terminal phenyl ring is directly connected to the piperazine core, showed an 
improved antiviral activity, revealing to be the best compound in this series, with an interesting antiviral profile against both viral strains.

All the evaluated molecules, except 39 and $\mathbf{5 2}$, were found not to be cytotoxic at the test concentrations in uninfected HEp-2 cells.

Table 1: $\mathrm{EC}_{50}$ and $\mathrm{CC}_{50}$ values of $\mathbf{1 , 3 9 - 5 3}$ in the $\mathrm{RSV}$ CPE reduction assay.

\begin{tabular}{|c|c|c|c|c|}
\hline Compound & Structure & $\begin{array}{l}\text { EC }_{50} \text { values } \\
{[\boldsymbol{\mu M}]^{\mathrm{A}, \mathrm{B}}}\end{array}$ & $\begin{array}{l}\text { EC }_{50} \text { values } \\
{[\mu \mathrm{M}]^{\mathrm{A}, \mathrm{C}}}\end{array}$ & $\begin{array}{l}\mathrm{CC}_{50} \text { values } \\
{[\boldsymbol{\mu M}]^{\mathrm{D}}}\end{array}$ \\
\hline 1 & $-\mathrm{CH}_{2} \mathrm{Ph}$ & $8.3^{\mathrm{C}}$ & $3.9 \pm 0.1$ & $>100$ \\
\hline 38 & $-\mathrm{CH}_{2}\left(4-\mathrm{OCH}_{3}-\mathrm{Ph}\right)$ & $12.9 \pm 13.8$ & $3.0 \pm 1.4$ & $>100$ \\
\hline 39 & $-\mathrm{CH}_{2}\left(4-\mathrm{C}\left(\mathrm{CH}_{3}\right)_{3}-\mathrm{Ph}\right)$ & $28.7 \pm 29.0$ & $2.2 \pm 1.5$ & $71.7 \pm 27.3$ \\
\hline 40 & $-\mathrm{CH}_{2}\left(4-\mathrm{COOCH}_{3}-\mathrm{Ph}\right)$ & $14.8 \pm 9.0$ & $3.9 \pm 0.1$ & $>100$ \\
\hline 41 & $-\mathrm{CH}_{2}\left(4-\mathrm{CH}_{3}-\mathrm{Ph}\right)$ & $17.9 \pm 19.6$ & 1.32 & $>100$ \\
\hline 42 & $-\mathrm{CH}_{2}\left(2,4-\mathrm{CH}_{3}-\mathrm{Ph}\right)$ & 4.97 & $15.0 \pm 19.2$ & $>100$ \\
\hline 43 & $-\mathrm{CH}_{2}\left(2,4,6-\mathrm{CH}_{3}-\mathrm{Ph}\right)$ & $42.2 \pm 40.7$ & 20.6 & $>100$ \\
\hline 44 & $-\mathrm{CH}_{2}\left(2-\mathrm{CH}_{3}-\mathrm{Ph}\right)$ & $10.4 \pm 3.2$ & 20.6 & $>100$ \\
\hline 45 & $-\mathrm{CH}_{2}\left(3-\mathrm{CH}_{3}-\mathrm{Ph}\right)$ & $11.8 \pm 8.9$ & $3.0 \pm 1.5$ & $>100$ \\
\hline 46 & $-\mathrm{CH}_{2}\left(4-\mathrm{COOCH}_{2} \mathrm{CH}_{3}-\mathrm{Ph}\right)$ & $40.8 \pm 13.3$ & $4.0 \pm 0.1$ & $>100$ \\
\hline 47 & $-\mathrm{CH}_{2}(4-\mathrm{F}-\mathrm{Ph})$ & $4.4 \pm 1.9$ & 2.5 & $>100$ \\
\hline 48 & $-\mathrm{CH}_{2}\left(3-\mathrm{CF}_{3}-\mathrm{Ph}\right)$ & $3.3 \pm 0.1$ & $3.8 \pm 0.1$ & $>100$ \\
\hline 49 & $-\mathrm{CH}_{2}\left(4-\mathrm{CF}_{3}-\mathrm{Ph}\right)$ & 3.31 & $4.7 \pm 6.7$ & $>100$ \\
\hline 50 & $-\mathrm{CH}_{2} \mathrm{CH}_{2} \mathrm{Ph}$ & $7.7 \pm 5.0$ & $13.6 \pm 18.9$ & $>100$ \\
\hline 51 & $-\mathrm{SO}_{2} \mathrm{Ph}$ & $35.3 \pm 15.2$ & $12.5 \pm 1.2$ & $>100$ \\
\hline 52 & $-\mathrm{COPh}$ & $44.1 \pm 15.2$ & 24.8 & $45.0 \pm 30.8$ \\
\hline 53 & $-\mathrm{Ph}$ & $4.4 \pm 1.1$ & $1.3 \pm 0.2$ & $>100$ \\
\hline ALS-8112 & - & $2.6 \pm 1.5$ & $2.6 \pm 1.5$ & $>100$ \\
\hline
\end{tabular}

${ }^{\mathrm{A}} \mathrm{EC}_{50}$ and $\mathrm{CC}_{50}$ values are the mean of at least 2 independent experiments, with standard deviations of $\pm 10 \%$ of the value quoted unless otherwise stated (mean value \pm standard deviations). CPE scoring in RSV/Hep2 cell culture system. ALS-8112 was used as positive control. 
${ }^{\text {B }}$ RSV-A strain

${ }^{\mathrm{C}} \mathrm{RSV}-\mathrm{B}$ strain

D Toxicity in Hep2 cell using viability staining with MTS.

${ }^{\mathrm{E}} \mathrm{EC}_{50}$ previously determined $=6 \mu \mathrm{M} \cdot{ }^{21}$

\subsection{Molecular modelling studies}

In order to identify a likely binding mode for the new derivatives to the M2-1 protein and rationalise the biological results obtained, a series of docking studies was performed on selected compounds $(\mathbf{1}, \mathbf{4 3}, \mathbf{4 8}, \mathbf{5 2}, \mathbf{5 3})$. The recently reported M2-1 protein complex crystal structure (PDB ID: 6G0Y) was used, and docking studies were performed using Glide SP scoring function. ${ }^{20,35}$ Compound $\mathbf{1}$ is predicted to lie in a large pocket formed by three monomers immediately above the zinc-binding domain (ZBD) of one of them (Figure 3A). The benzothiazole ring occupies the entrance of the binding site with its sulphur atom oriented towards the oxygen atom of the GlyA18 backbone and it is involved in a $\pi$-interaction with LysB113. The unsubstituted benzyl ring is placed in the inner portion of the pocket, involved in a sandwich $\pi$-stacking interaction with HisA14, which probably holds in place this part of the molecule. The central piperazine ring establishes multiple interactions with AspB109, which locks 1 in a conformation that allows the sulphur atom of the thiocarbamate moiety to be oriented towards the Zn-binding domain. Moreover, the piperazine ring interacts with Cys15A, one of the three cysteine residues involved in the coordination of the $\mathrm{Zn}$ atom. A similar occupation of the pocket and interactions were found for 48 (Figure 3B), with the only difference in the benzyl ring positioning. In fact, the $m-\mathrm{CF}_{3}$ group, potentially due to steric hindrance, forces the ring to occupy the pocket in a different position, with the sulphur atom remaining close to the $\mathrm{Zn}$-binding domain. Moreover, the piperazine ring forms a $\pi$-interaction with HisA25, another residue involved in the $\mathrm{Zn}$ atom coordination. The shorter derivative $\mathbf{5 3}$ occupies the binding cavity similarly to 48 (Figure 3C). Interestingly, no docking results were obtained for derivative 43. Potentially, the tri-substituted benzyl ring, due to steric hindrance, does not fit into the inner part of the binding area, not allowing the rest of the molecule to correctly bind to the active site, possibly explaining the large reduction in antiviral activity found for this compound.

On the other hand, compound $\mathbf{5 2}$ occupies the pocket in a different orientation if compared with the other active derivatives, placing the carbonyl group in correspondence of the $\mathrm{Zn}$ - 
binding area, driven by its interaction with the backbone of GlyA18, therefore forcing the thiocarbamate moiety to point away from this area, impeding its interaction with the $\mathrm{Zn}$ atom and the surrounding residues (Figure 3D).
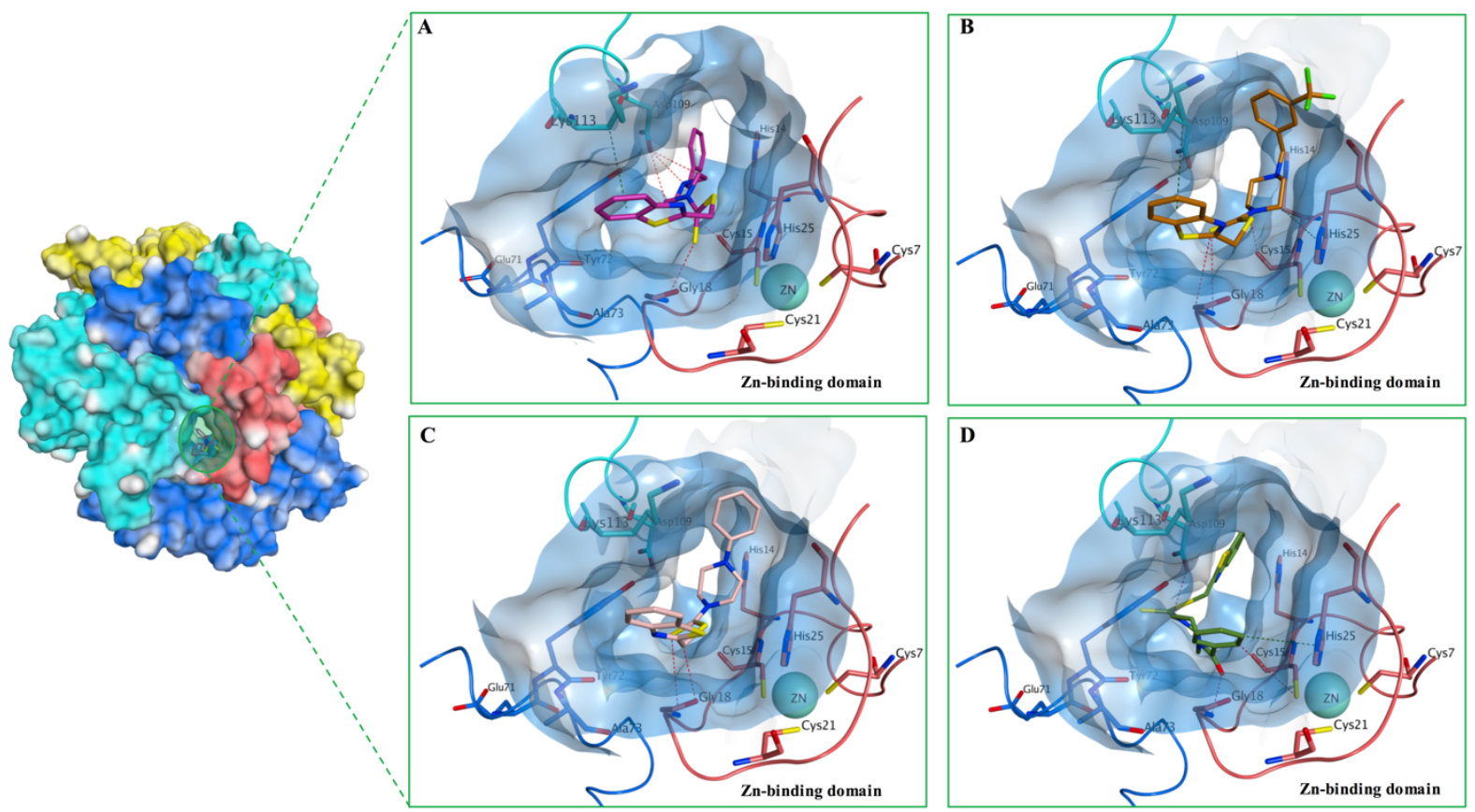

Figure 3: Proposed binding mode for compounds 1 (A), 48 (B), 53 (C), 52 (D) in the ZBD of the M2-1 protein (PDB ID: 6G0Y). Compounds bind in a large pocket formed by three monomers immediately above the zinc-binding domain (ZBD) of one of them. Importantly, the sulphur atom of the thiocarbamate moiety is always oriented towards the ZBD except for $\mathbf{5 2}$. The single monomers of M2-1 protein forming the functional tetramers are represented as molecular surface and ribbons: monomer A in salmon, monomer B in turquoise, monomer C in blue, monomer $\mathrm{D}$ in yellow. The residues of the different monomers are coloured accordingly. Carbon atoms of compound $\mathbf{1}$ are shown in purple, in orange for $\mathbf{4 8}$, in pink for $\mathbf{5 3}$ and in green for $\mathbf{5 2}$. The ZBD of monomer A is labelled.

In order to validate the suggested binding mode, a series of $150 \mathrm{~ns}$ molecular dynamics (MD) simulations on 1, 48 and 53 were performed, using the Desmond software package for MD simulations. ${ }^{36}$ All the protein-ligand systems reached stability after an initial $70 \mathrm{~ns}$ of equilibration, as showed by the C-alpha RMSD variation, therefore only the remaining $80 \mathrm{~ns}$ of the simulation were considered in our analysis (Figure 4). 


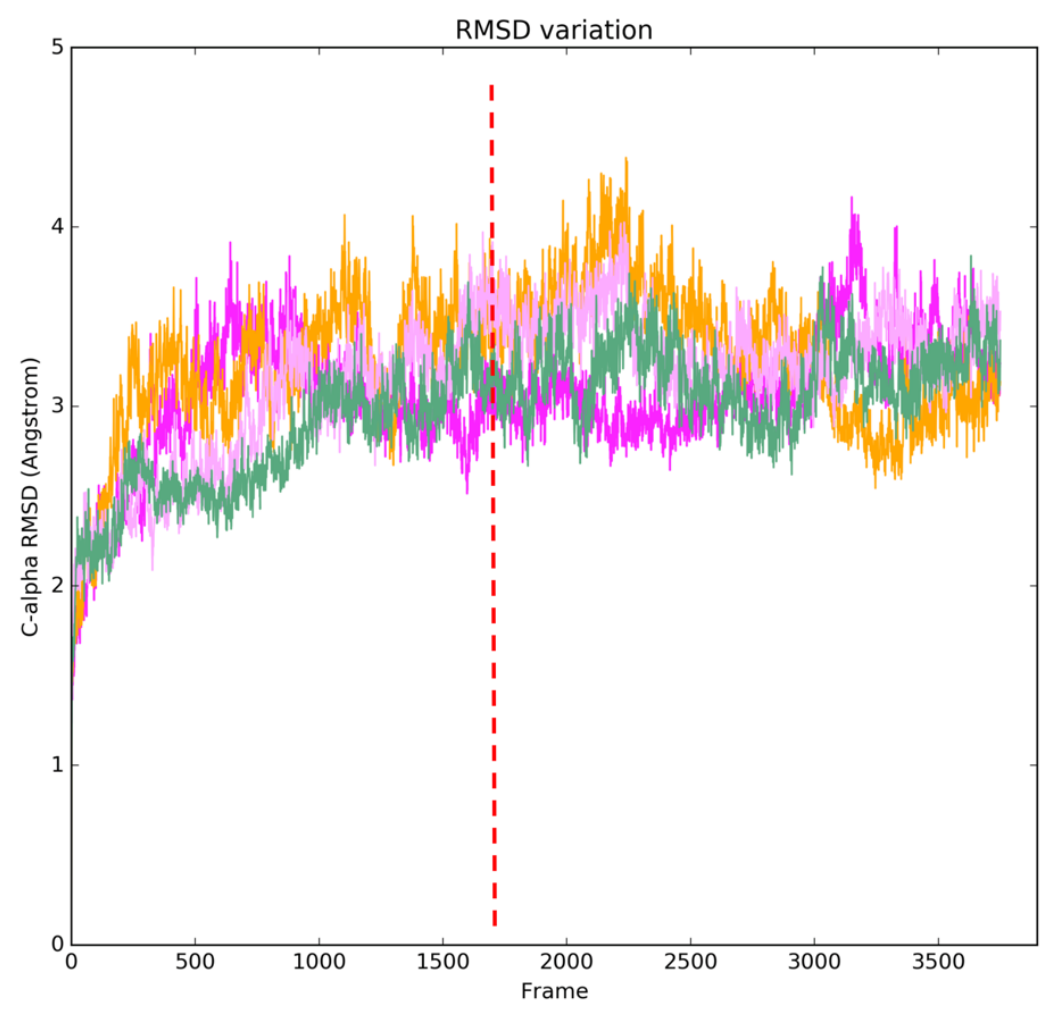

Figure 4: Plots of RMSD $(\AA)$ values against simulation frames for protein-inhibitor complexes. After $70 \mathrm{~ns}$ of equilibration (red dotted line, corresponding to frame 1750), the proteins reach stability (C-alpha RMSD variation). Only one replicate is shown for each different protein-ligand complex. Color legend: 1-protein (purple), 48-protein (orange), 53protein (pink), 52-protein (green).

In general, all the three molecules tend to optimise their occupation of the binding site maintaining then a stable pose during the entire MD simulation, with the thiocarbamate moiety always oriented and placed nearby the Zn-binding domain. (Figure 5A, example of compound 1). In particular, the initial ligand-protein interactions with HisA14 (hydrophobic interactions) and LysB113 (alternation between hydrophobic interaction and water bridges) are maintained for most of the MD simulation (Figure 5B). The initial interactions between the piperazine ring and AspB109 are then mediated by a water bridge, whereas an extra interaction between the benzothiazole ring of all the tree derivatives and residue $\mathrm{TyrC} 72$ is formed (either as hydrophobic contact or water bridge) and maintained during the entire simulation, potentially contributing to the protein-ligand complex stability. As negative control, a MD simulation for 52 was also performed. The starting binding pose was maintained for the entire simulation, with the thiocarbamate moiety always pointing away from the Zn-binding domain. 
A

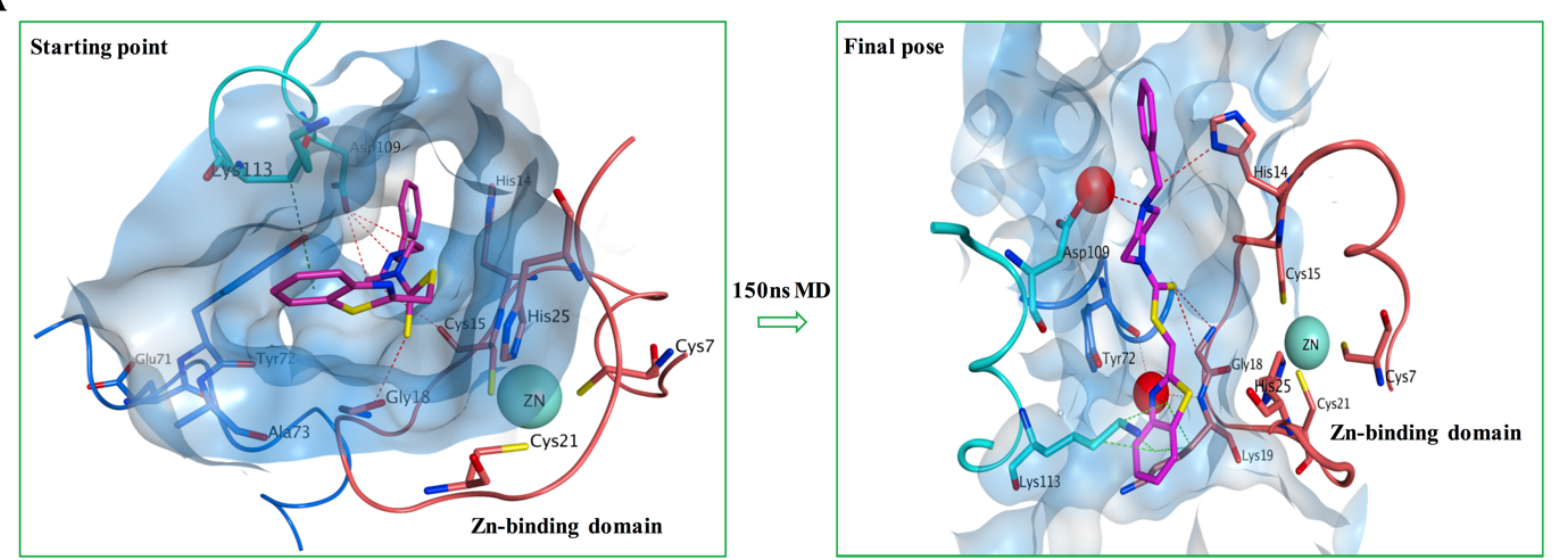

B

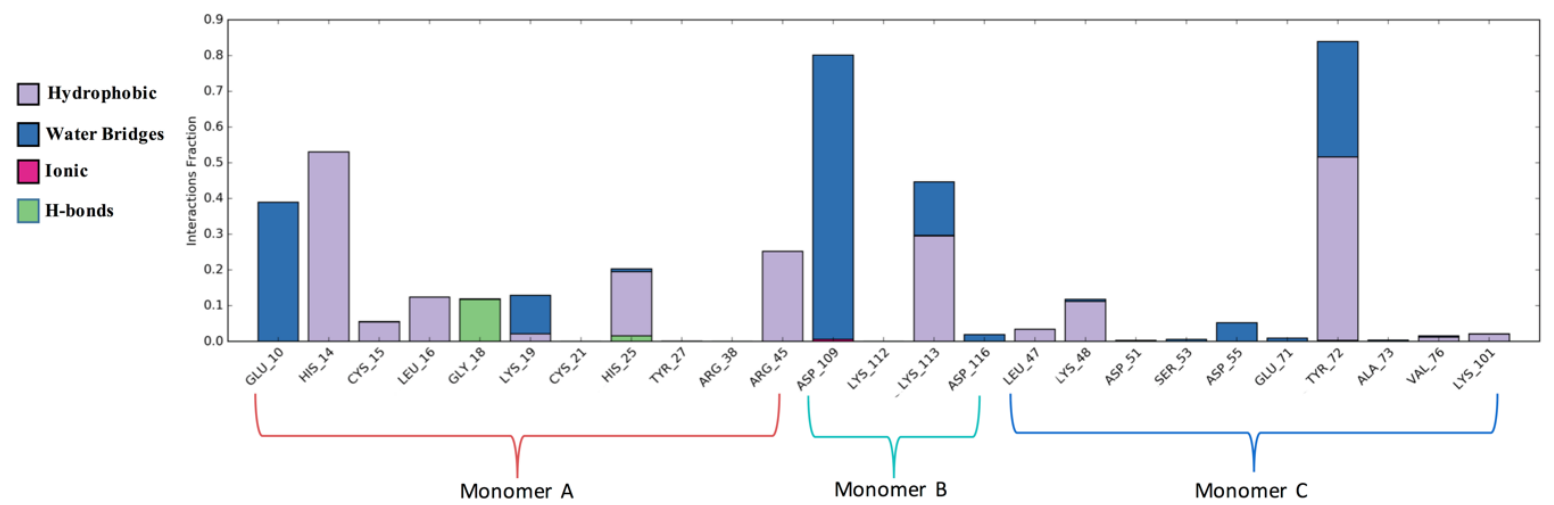

Figure 5: A) Proposed binding mode for 1 at the beginning of the MD simulation and after $150 \mathrm{~ns} .1$ tends to optimise its occupation of the binding site with the thiocarbamate moiety always oriented and placed nearby the Zn-binding domain. Carbon atoms of $\mathbf{1}$ are shown in purple, molecules of water as red spheres. The final pose shown is from the last frame of only one replicate of the MD simulation for the 1-protein complex. B) Compound 1-protein contacts monitored throughout the MD simulation. The stacked bar charts are normalised by the program over the course of the trajectory: a value of 0.8 suggests that a specific interaction is maintained for $80 \%$ of the simulation time. Only the simulation time between 80 ns and 150 ns (after equilibration of the system as discussed above) was considered in our analysis. The analysis of only one MD replicate is shown.

To confirm the stability of these protein-ligand complexes, the compounds relative binding free energies ( $\Delta \mathrm{G}_{\text {binding }}$ ) were then calculated using the Prime/MM-GBSA based calculation

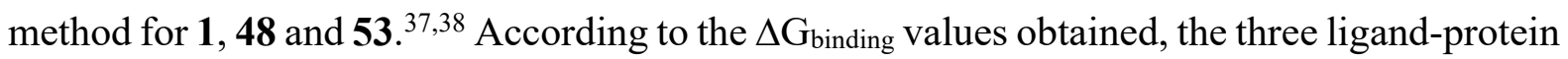
complexes show similar results, in line with the similar biological activities found for these three molecules (Table 2). In conclusion, molecular docking and MD studies have given important elucidations on the potential binding mode for this family of compounds. The 
information thus obtained will be used to perform further structural modifications on the current scaffold.

Table 2: Calculated ligand-interaction energies for the compounds analysed after the molecular dynamics simulations.

\begin{tabular}{|c|c|}
\hline Compound & $\Delta \mathbf{G}_{\text {binding }}(\mathbf{k J} / \mathbf{m o l})^{\mathbf{a}} \pm \mathbf{S D}$ \\
\hline $\mathbf{1}$ & $-47.40 \pm 6.39$ \\
$\mathbf{4 8}$ & $-42.80 \pm 8.40$ \\
$\mathbf{5 3}$ & $-43.07 \pm 4.45$ \\
\hline
\end{tabular}

a Average values calculated as mean of three of $\Delta \mathrm{G}_{\text {binding }}$ obtained from three indipendent MD simulations (triplicate) for each compound. For each replicate, the average $\Delta \mathrm{G}_{\text {binding }}$ value was calculated excluding the first $70 \mathrm{~ns}$ of MD, in which the system protein-ligand reached stability. Standard deviation (SD) is reported.

\section{Conclusions}

Starting from an anti-RSV hit we had previously identified with an in silico structure-based approach and applying standard medicinal chemistry modifications, a family of 16 new derivatives has been designed and synthesised. All newly prepared compounds were evaluated for their potential antiviral activity in a cytophatic effect (CPE)-based in vitro assay in HEp-2 cells, using two different RSV strains, RSV-A and RSV-B. Among them, different displayed retained activity, including the original hit $\mathbf{1}$, with no cytotoxic associated, confirming the antiRSV profile associated with this new scaffold. Most interestingly, 53, in which the terminal phenyl ring is directly connected to the piperazine core, was found as the best compound in this series, with an interesting antiviral profile against both viral strains, with $\mathrm{EC}_{50}$ values in the low $\mu \mathrm{M}$ range. Molecular modelling studies revealed important information on the potential binding mode of this family of compounds to their putative target, the viral M2-1 protein.

In conclusion, the antiviral activity associated with this chemical scaffold has been confirmed and the phenyl derivative $\mathbf{5 3}$ was found to be an effective anti-RSV inhibitor with no toxicity associated. The biological and in silico results obtained represent a promising starting point for 
further structure-activity relationship enhancement, in order to improve potency in the quest for an effective antiviral treatment for human RSV infections.

\section{Experimental section}

\subsection{General Chemistry methods, general procedures and compound characterisation examples}

All solvents and reagents were used as obtained from commercial sources unless otherwise indicated. All solvents used for chromatography were HPLC grade from Fisher Scientific (UK). All reactions were performed under a nitrogen atmosphere. ${ }^{1} \mathrm{H}$ and ${ }^{13} \mathrm{C}-\mathrm{NMR}$ spectra were recorded with a Bruker Avance III HD spectrometer operating at $500 \mathrm{MHz}$ for ${ }^{1} \mathrm{H}$ and $125 \mathrm{MHz}$ for ${ }^{13} \mathrm{C}$, with $\mathrm{Me}_{4} \mathrm{Si}$ as internal standard. Deuterated chloroform was used as the solvent for NMR experiments, unless otherwise stated. ${ }^{1} \mathrm{H}$ chemical shifts values $(\delta)$ are referenced to the residual non-deuterated components of the NMR solvents $(\delta=7.26 \mathrm{ppm}$ for $\mathrm{CHCl}_{3}$, etc.). The ${ }^{13} \mathrm{C}$ chemical shifts $(\delta)$ are referenced to $\mathrm{CDCl}_{3}$ (central peak, $\delta=77.0 \mathrm{ppm}$ ). TLC was performed on silica gel 60 F254 plastic sheets. Flash column chromatography was performed using silica on an Biotage Isolera 1 system. Melting points were determined on an electro-thermal instrument, Griffin apparatus and are uncorrected. UPLC-MS analysis was conducted on a Waters UPLC system with both Diode Array detection and Electrospray (+'ve and -'ve ion) MS detection. The stationary phase was a Waters Acquity UPLC BEH C18 1.7um $2.1 \times 50 \mathrm{~mm}$ column. The mobile phase was LC-MS grade $\mathrm{H}_{2} \mathrm{O}$ containing $0.1 \%$ formic acid (A) and LC-MS grade MeCN containing 0.1\% formic acid (B). Column temperature: $40{ }^{\circ} \mathrm{C}$. Sample diluent: MeCN. Sample concentration $1 \mu \mathrm{g} / \mathrm{mL}$. Injection volume $2 \mu \mathrm{L}$. Three alternative methods were used:

Linear gradient standard method (A): 90\% A (0.1 min), 90\%-0\% A (2.5 min), 0\% A (0.3 min), $90 \% \mathrm{~A}(0.1 \mathrm{~min})$; flow rate $0.5 \mathrm{~mL} / \mathrm{min}$.

Linear gradient standard method (B): $90 \%$ A (0.1 min), 90\%-0\% A (2.1 min), 0\% A (0.8 min), $90 \%$ A $(0.1 \mathrm{~min})$; flow rate $0.5 \mathrm{~mL} / \mathrm{min}$.

Linear gradient standard method (C): 90\% A (0.1 min), 90\%-0\% A (1.5 min), 0\% A (1.4 min), 90\% A $(0.1 \mathrm{~min})$; flow rate $0.5 \mathrm{~mL} / \mathrm{min}$.

All compounds tested in biological assays were $>95 \%$ pure. Purity of intermediates was $>90 \%$, unless otherwise stated. All intermediates were generally prepared according to literature procedures, which are described in detail along with compound characterisation in the 
Supporting Information. Details for the preparation and full characterisation of the new target final compounds are given below.

\subsubsection{General method A for the preparation of final compounds 38-46}

To a solution of substituted benzyl-piperazine $(2 \mathrm{mmol})$ in dimethylformamide $(5 \mathrm{~mL})$ was added carbon disulphide $(2 \mathrm{mmol})$ and sodium methoxide at $0{ }^{\circ} \mathrm{C}$ and it was stirred for $30 \mathrm{~min}$. 2-Chloromethyl benzothiazole (5) $(1 \mathrm{mmol})$ was added in one portion, the reaction mixture was left to reach room temperature and stirring was continued until the reaction was complete (monitoring by TLC). The reaction mixture was quenched by addition of ice-cold water and then it was extracted with EtOAc $(25 \mathrm{~mL})$, dried over $\mathrm{MgSO}_{4}$ and evaporated to give the crude product. Purification by flash column chromatography ( $n$-hexane:EtOAc 100:0 v/v, increasing to $80: 20 \mathrm{v} / \mathrm{v}$ ) gave the pure product.

\subsubsection{Benzo $[d]$ thiazol-2-ylmethyl 4-(4-methoxybenzyl)piperazine-1-carbodithioate (38)}

Obtained in $75 \%$ yield as a white solid. ${ }^{1} \mathrm{H}-\mathrm{NMR}\left(\mathrm{CDCl}_{3}\right) \delta: 2.52$ (bs, $4 \mathrm{H}, \mathrm{CH}_{2}$-piperazine), $3.48\left(\mathrm{~s}, 2 \mathrm{H}, \mathrm{CH}_{2}\right), 3.78$ (s, 3H, $\left.-\mathrm{OCH}_{3}\right), 3.93$ (bs, $2 \mathrm{H}, \mathrm{CH}_{2}$-piperazine), 4.35 (bs, $2 \mathrm{H}, \mathrm{CH}_{2}-$ piperazine), 5.11 (s, 2H, CH 2 ), 6.79 (d, J=8.6 Hz, 2H, H-aromatic), 7.14 (d, J=8.6 Hz, 2H, Haromatic), 7.35-7.38 (m, 1H, H-aromatic), 7.44-7.47 (m, 1H, H-aromatic), 7.81-7.84 (m, 1H, H-aromatic), 7.97-8.00 (m, 1H, H-aromatic). ${ }^{13} \mathrm{C}-\mathrm{NMR}\left(\mathrm{CDCl}_{3}\right) \delta: 38.9\left(\mathrm{CH}_{2}\right), 52.2\left(\mathrm{CH}_{2}\right)$, $55.2\left(\mathrm{CH}_{3}\right), 61.8\left(\mathrm{CH}_{2}\right), 113.7,121.6,122.9,125.2,126.0,(\mathrm{CH}, \mathrm{C}$-aromatic $), 129.2(\mathrm{C}), 130.3$ (CH, C-aromatic), 135.7, 152.7, 159.0, 167.7, 194.2 (C). Melting point: 81-83 C. UPLC-MS (Method C): $\mathrm{R}_{\mathrm{t}} 1.67 \mathrm{~min}, \mathrm{MS}$ [ESI, m/z]: $430.2\left[\mathrm{M}+\mathrm{H}\right.$ ]. Anal. Calcd for $\mathrm{C}_{21} \mathrm{H}_{23} \mathrm{~N}_{3} \mathrm{OS}_{3}: \mathrm{C}$, 58.71; H, 5.40; N, 9.78. Found: C, 58.86; H, 5.20; N, 9.71.

\subsubsection{Benzo[d] thiazol-2-ylmethyl4-(4-(tert-butyl)benzyl) piperazine-1-carbodithioate (39)} Obtained in $69 \%$ yield as a yellow waxy solid. ${ }^{1} \mathrm{H}-\mathrm{NMR}\left(\mathrm{CDCl}_{3}\right) \delta: 1.31\left(\mathrm{~s}, 9 \mathrm{H}, \mathrm{CH}_{3}\right.$ tertbutyl), 2.54 (bs, 4H, $\mathrm{CH}_{2}$-piperazine), 3.51 (s, 2H, $\mathrm{CH}_{2}$ ), 3.95 (bs, 2H, $\mathrm{CH}_{2}$-piperazine), 4.37 (bs, 2H, $\mathrm{CH}_{2}$-piperazine), 5.11 (s, 2H, $\mathrm{CH}_{2}$ ), 7.23 (d, J=8.3 Hz, 2H, H-aromatic), 7.33-7.38 (m, 3H, H-aromatic), 7.44-7.47 (m, 1H, H-aromatic), 7.81-7.84 (m, 1H, H-aromatic), 7.97-8.00 (m, 1H, H-aromatic). ${ }^{13} \mathrm{C}-\mathrm{NMR}\left(\mathrm{CDCl}_{3}\right) \delta: 31.3\left(\mathrm{CH}_{3}\right), 38.9\left(\mathrm{CH}_{2}\right), 52.3\left(\mathrm{CH}_{2}\right), 62.1\left(\mathrm{CH}_{2}\right)$, 68.1 (C), 121.6, 122.9, 125.2, 125.3, 126.0, 128.8 (CH, C-aromatic), 130.8, 135.7, 150.4, 152.7, 167.7, 194.2 (C). Melting point: $73-75^{\circ}$ C. UPLC-MS (Method C): $\mathrm{R}_{\mathrm{t}} 1.89 \mathrm{~min}, \mathrm{MS}$ [ESI, m/z]: $456.2[\mathrm{M}+\mathrm{H}]$. Anal. Calcd for $\mathrm{C}_{24} \mathrm{H}_{29} \mathrm{~N}_{3} \mathrm{~S}_{3}: \mathrm{C}, 63.26 ; \mathrm{H}, 6.41 ; \mathrm{N}, 9.22$. Found: $\mathrm{C}, 63.22 ; \mathrm{H}$, $6.59 ; \mathrm{N}, 9.05$. 
4.1.4 Methyl4-((4-(((benzo[ $d]$ thiazol-2-ylmethyl) thio) carbonothioyl) piperazin-1-yl) methyl) benzoate (40)

Obtained in 76\% yield as a yellow solid. ${ }^{1} \mathrm{H}-\mathrm{NMR}\left(\mathrm{CDCl}_{3}\right) \delta: 2.55$ (bs, $4 \mathrm{H}, \mathrm{CH}_{2}$-piperazine), 3.58 (s, 2H, $\mathrm{CH}_{2}$ ), 3.91 (s, 3H, CH3 methyl ester), 3.95 (bs, 2H, $\mathrm{CH}_{2}$-piperazine), 4.37 (bs, $2 \mathrm{H}$, $\mathrm{CH}_{2}$-piperazine), 5.11 (s, 2H, $\mathrm{CH}_{2}$ ), 7.41-7.35 (m, 3H, H-aromatic), 7.44-7.47 (m, 1H, Haromatic), 7.81-7.83 (m, 1H, H-aromatic), 7.97-8.01 (m, 3H, $\mathrm{H}$-aromatic). ${ }^{13} \mathrm{C}-\mathrm{NMR}\left(\mathrm{CDCl}_{3}\right)$

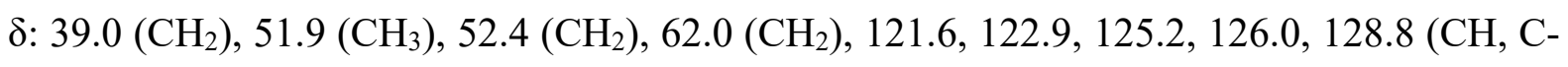
aromatic), 129.4 (C), 129.7 (CH, C-aromatic), 135.7, 142.7, 152.7, 166.9, 167.6, 194.4 (C). Melting point: $83-85^{\circ}$ C. UPLC-MS (Method C): $\mathrm{R}_{\mathrm{t}} 1.79 \mathrm{~min}, \mathrm{MS}$ [ESI, m/z]: 458.2 [M+H]. Anal. Calcd for $\mathrm{C}_{22} \mathrm{H}_{23} \mathrm{~N}_{3} \mathrm{O}_{2} \mathrm{~S}_{3}$ : C, 57.74; H, 5.07; N, 9.18. Found: C, 57.89; H, 4.88; N, 8.93.

\subsubsection{Benzo[d]thiazol-2-ylmethyl 4-(4-methylbenzyl)piperazine-1-carbodithioate (41)}

Obtained in 49\% yield as a yellow solid. ${ }^{1} \mathrm{H}-\mathrm{NMR}\left(\mathrm{CDCl}_{3}\right) \delta: 2.33\left(\mathrm{~s}, 3 \mathrm{H}, \mathrm{CH}_{3}\right), 2.54(\mathrm{bs}, 4 \mathrm{H}$, $\mathrm{CH}_{2}$-piperazine), 3.50 (s, 2H, $\mathrm{CH}_{2}$ ), 3.95 (bs, 2H, $\mathrm{CH}_{2}$-piperazine), 4.36 (bs, $2 \mathrm{H}, \mathrm{CH}_{2}$ piperazine), 5.12 (s, 2H, CH 2$), 7.16$ (d, J=7.8 Hz, 2H, H-aromatic), 7.21 (d, J=7.8 Hz, 2H, Haromatic)7.35-7.38 (m, 1H, H-aromatic), 7.45-7.48 (m, 1H, H-aromatic), 7.82-7.84 (m, 1H, Haromatic), 7.97-7.99 (m, 1H, H-aromatic). ${ }^{13} \mathrm{C}-\mathrm{NMR}\left(\mathrm{CDCl}_{3}\right) \delta: 21.1\left(\mathrm{CH}_{3}\right), 38.9\left(\mathrm{CH}_{2}\right), 52.3$ $\left(\mathrm{CH}_{2}\right), 62.1\left(\mathrm{CH}_{2}\right), 121.6,122.9,125.2,126.0,129.1,129.1$ (CH, C-aromatic), 135.7, 137.1, 152.7, 159.1, 167.7, 194.2 (C). Melting point: 95-97 C. UPLC-MS (Method C): $\mathrm{R}_{\mathrm{t}} 1.74 \mathrm{~min}$, MS [ESI, m/z]: $414.2[\mathrm{M}+\mathrm{H}]$. Anal. Calcd for $\mathrm{C}_{21} \mathrm{H}_{23} \mathrm{~N}_{3} \mathrm{~S}_{3}: \mathrm{C}, 60.98 ; \mathrm{H}, 5.61 ; \mathrm{N}, 10.16$. Found: C, 61.04; H, 5.34; N, 10.03.

\subsubsection{Benzo $[d]$ thiazol-2-ylmethyl4-(2,4-dimethylbenzyl) piperazine-1-carbodithioate (42)}

Obtained in 38\% yield as a yellow waxy solid. ${ }^{1} \mathrm{H}-\mathrm{NMR}\left(\mathrm{CDCl}_{3}\right): 2.30\left(\mathrm{~s}, 3 \mathrm{H}, \mathrm{CH}_{3}\right), 2.33$ (s, $3 \mathrm{H}, \mathrm{CH}_{3}$ ), 2.53 (bs, 4H, $\mathrm{CH}_{2}$-piperazine), 3.46 (s, 2H, $\mathrm{CH}_{2}$ ), 3.91 (bs, 2H, $\mathrm{CH}_{2}$-piperazine), 4.34 (bs, 2H, $\mathrm{CH}_{2}$-piperazine), 5.11 (s, 2H, $\mathrm{CH}_{2}$ ), 6.95-7.00 (m, 2H, H-aromatic), 7.09 (d, J= $7.5 \mathrm{~Hz}, 2 \mathrm{H}, \mathrm{H}$-aromatic), 7.35-7.38 (m, 1H, H-aromatic), 7.44-7.47 (m, 1H, H-aromatic), 7.817.83 (m, 1H, H-aromatic), 7.97-7.99 (m, 1H, H-aromatic). ${ }^{13} \mathrm{C}-\mathrm{NMR}\left(\mathrm{CDCl}_{3}\right) \delta: 19.1\left(\mathrm{CH}_{3}\right)$, $21.0\left(\mathrm{CH}_{3}\right), 38.9\left(\mathrm{CH}_{2}\right), 52.4\left(\mathrm{CH}_{2}\right), 60.10\left(\mathrm{CH}_{2}\right), 121.6,122.9,125.23,126.0,126.2,130.0$, 131.3 (CH, C-aromatic), 135.7, 137.4, 150.4, 152.7, 166.9, 167.7, 194.2 (C). Melting point: 68-70 ${ }^{\circ}$ C. UPLC-MS (Method C): $\mathrm{R}_{\mathrm{t}} 1.87 \mathrm{~min}, \mathrm{MS}$ [ESI, m/z]: 428.2 [M+H]. Anal. Calcd for $\mathrm{C}_{22} \mathrm{H}_{25} \mathrm{~N}_{3} \mathrm{~S}_{3}$ : C, 61.79; H, 5.89; N, 9.83. Found: C, 61.56; H, 6.07; N, 9.65.

\subsubsection{Benzo $[d]$ thiazol-2-ylmethyl4-(2,4,6-trimethylbenzyl) piperazine-1-carbodithioate} (43)

Obtained in 68\% yield as a yellow waxy solid. ${ }^{1} \mathrm{H}-\mathrm{NMR}\left(\mathrm{CDCl}_{3}\right): 2.26\left(\mathrm{~s}, 3 \mathrm{H}, \mathrm{CH}_{3}\right), 2.33$ (s, $6 \mathrm{H}, \mathrm{CH}_{3}$ ), 2.54 (bs, 4H, $\mathrm{CH}_{2}$-piperazine), 3.49 (s, 2H, $\mathrm{CH}_{2}$ ), 3.88 (bs, 2H, $\mathrm{CH}_{2}$-piperazine), 
4.31 (bs, 2H, $\mathrm{CH}_{2}$-piperazine), 5.29 (s, 2H, $\mathrm{CH}_{2}$ ), 6.84 (s, 2H, H-aromatic), 7.34-7.38 (m, 1H, $\mathrm{H}$-aromatic), 7.44-7.47 (m, 1H, H-aromatic), 7.81-7.83 (m, 1H, H-aromatic), 7.97-7.99 (m, 1H, H-aromatic). ${ }^{13} \mathrm{C}-\mathrm{NMR}\left(\mathrm{CDCl}_{3}\right) \delta: 20.0\left(\mathrm{CH}_{3}\right), 20.9\left(\mathrm{CH}_{3}\right), 38.9\left(\mathrm{CH}_{2}\right), 52.0\left(\mathrm{CH}_{2}\right), 55.2\left(\mathrm{CH}_{2}\right)$, 121.6,122.9, 125.2, 126.0, 129.0 (CH, C-aromatic), 130.8, 135.7, 136.8, 138.0, 152.7, 167.8, 194.0 (C). Melting point: $82-84^{\circ}$ C. UPLC-MS (Method C): $\mathrm{R}_{\mathrm{t}} 2.10 \mathrm{~min}$, MS [ESI, m/z]: 442.2 $[\mathrm{M}+\mathrm{H}]$. Anal. Calcd for $\mathrm{C}_{23} \mathrm{H}_{27} \mathrm{~N}_{3} \mathrm{~S}_{3}: \mathrm{C}, 62.55 ; \mathrm{H}, 6.16 ; \mathrm{N}, 9.51$. Found: $\mathrm{C}, 62.29 ; \mathrm{H}, 6.01 ; \mathrm{N}$, 9.75 .

\subsubsection{Benzo $[d]$ thiazol-2-ylmethyl 4-(2-methylbenzyl)piperazine-1-carbodithioate (44)}

Obtained in $72 \%$ yield as a light brown waxy solid. ${ }^{1} \mathrm{H}-\mathrm{NMR}\left(\mathrm{CDCl}_{3}\right): 2.37\left(\mathrm{~s}, 3 \mathrm{H}, \mathrm{CH}_{3}\right), 2.54$ (bs, 4H, $\mathrm{CH}_{2}$-piperazine), 3.49 (s, 2H, $\mathrm{CH}_{2}$ ), 3.92 (bs, 2H, $\mathrm{CH}_{2}$-piperazine), 4.35 (bs, 2H, $\mathrm{CH}_{2}$ piperazine), 5.12 (s, 2H, CH 2$), 7.13-7.23$ (m, 4H, H-aromatic), 7.35-7.38 (m, 1H, H-aromatic), 7.44-7.47 (m, 1H, H-aromatic), 7.81-7.83 (m, 1H, H-aromatic), 7.97-7.99 (m, 1H, H-aromatic). ${ }^{13} \mathrm{C}-\mathrm{NMR}\left(\mathrm{CDCl}_{3}\right) \delta: 19.2\left(\mathrm{CH}_{3}\right), 38.9\left(\mathrm{CH}_{2}\right), 52.4\left(\mathrm{CH}_{2}\right), 60.36\left(\mathrm{CH}_{2}\right), 121.6,122.9,125.2$, 125.6, 126.0, 127.5, 129.9, 130.4 (CH, C-aromatic), 135.7, 137.6, 152.7, 166.9, 167.7, 194.2 (C). Melting point: $98-100^{\circ}$ C. UPLC-MS (Method C): $\mathrm{R}_{\mathrm{t}} 1.79 \mathrm{~min}$, MS [ESI, m/z]: 414.2 $[\mathrm{M}+\mathrm{H}]$. Anal. Calcd for $\mathrm{C}_{21} \mathrm{H}_{23} \mathrm{~N}_{3} \mathrm{~S}_{3}$ : C, 60.98; H, 5.61; N, 10.16. Found: C, 61.16; H, 5.37; N, 10.09 .

\subsubsection{Benzo $[d]$ thiazol-2-ylmethyl 4-(3-methylbenzyl)piperazine-1-carbodithioate (45)}

Obtained in 45\% yield as a yellow waxy solid. ${ }^{1} \mathrm{H}-\mathrm{NMR}\left(\mathrm{CDCl}_{3}\right): 2.35\left(\mathrm{~s}, 3 \mathrm{H}, \mathrm{CH}_{3}\right), 2.55(\mathrm{bs}$, $4 \mathrm{H}, \mathrm{CH}_{2}$-piperazine), 3.51 (s, 2H, $\mathrm{CH}_{2}$ ), 3.96 (bs, 2H, $\mathrm{CH}_{2}$-piperazine), 4.36 (bs, $2 \mathrm{H}, \mathrm{CH}_{2}$ piperazine), $5.12\left(\mathrm{~s}, 2 \mathrm{H}, \mathrm{CH}_{2}\right), 7.09-7.14$ (m, 3H, H-aromatic), 7.20-7.23 (m, 1H, H-aromatic), 7.35-7.38 (m, 1H, H-aromatic), 7.44-7.48 (m, 1H, H-aromatic), 7.82-7.84 (m, 1H, H-aromatic), 7.98-8.00 (m, 1H, H-aromatic). ${ }^{13} \mathrm{C}-\mathrm{NMR}\left(\mathrm{CDCl}_{3}\right) \delta: 21.3\left(\mathrm{CH}_{3}\right), 39.0\left(\mathrm{CH}_{2}\right), 52.2\left(\mathrm{CH}_{2}\right), 62.3$ $\left(\mathrm{CH}_{2}\right), 121.6,122.9,125.2,126.0,126.4,128.4,128.5,130.0$ (CH, C-aromatic), 135.7, 138.2, 152.7, 167.6, 168.4194 .4 (C). Melting point: 48-50 C. UPLC-MS (Method C): $\mathrm{R}_{\mathrm{t}} 1.75 \mathrm{~min}$, MS [ESI, m/z]: $414.2[\mathrm{M}+\mathrm{H}]$. Anal. Calcd for $\mathrm{C}_{21} \mathrm{H}_{23} \mathrm{~N}_{3} \mathrm{~S}_{3}: \mathrm{C}, 60.98 ; \mathrm{H}, 5.61 ; \mathrm{N}, 10.16$. Found: C, 61.09; H, 5.82; N, 10.02 .

\subsubsection{Benzo $[d]$ thiazol-2-ylmethyl4-(4-propionylbenzyl) piperazine-1-carbodithioate (46)}

Obtained in $43 \%$ yield as a light brown waxy solid. ${ }^{1} \mathrm{H}-\mathrm{NMR}\left(\mathrm{CDCl}_{3}\right): 1.39\left(\mathrm{t}, \mathrm{J}=7.1,3 \mathrm{H}, \mathrm{CH}_{3}\right)$, 2.54 (bs, 4H, $\mathrm{CH}_{2}$-piperazine), 3.58 (s, 2H, $\mathrm{CH}_{2}$ ), 3.96 (bs, 2H, $\mathrm{CH}_{2}$-piperazine), 4.42-4.33 (m, $4 \mathrm{H}, \mathrm{CH}_{2}$ piperazine and $\mathrm{CH}_{2}$ ethyl ester), 5.10 (s, 2H, $\left.\mathrm{CH}_{2}\right), 7.35-7.39$ (m, 1H, H-aromatic), 7.40 (d, J= 8.2 Hz, 2H, H-aromatic), 7.44-7.47 (m, 1H, H-aromatic), 7.81-7.83 (m, 1H, Haromatic), 7.97-8.00 (m, 1H, H-aromatic), 8.01 (d, J=8.2 Hz, 2H, H-aromatic). ${ }^{13} \mathrm{C}-\mathrm{NMR}$ $\left(\mathrm{CDCl}_{3}\right) \delta$ : $14.3\left(\mathrm{CH}_{3}\right), 39.0\left(\mathrm{CH}_{2}\right), 52.4\left(\mathrm{CH}_{2}\right), 60.98\left(\mathrm{CH}_{2}\right), 62.03\left(\mathrm{CH}_{2}\right), 121.6,122.9,125.2$, 
126.0, 128.9, 129.7 (CH, C-aromatic), 133.9, 135.7, 138.2, 152.7, 166.4, 167.6, 194.5 (C). Melting point: $70-72^{\circ}$ C. UPLC-MS (Method C): $\mathrm{R}_{\mathrm{t}}$ 1.89min, MS [ESI, m/z]: 472.1 [M+H]. Anal. Calcd for $\mathrm{C}_{23} \mathrm{H}_{25} \mathrm{~N}_{3} \mathrm{O}_{2} \mathrm{~S}_{3}$ : C, 58.57; H, 5.34; N, 8.91. Found: C, 58.34; H, 5.19; N, 9.14.

\subsubsection{General method $B$ for the preparation of final compounds 47-53}

To an ethanolic solution of potassium hydroxide $(1 \mathrm{mmol} / 100 \mathrm{~mL})$ a secondary amine $(1 \mathrm{mmol})$ was added. The mixture was cooled in an ice-bath and carbon disulphide $(10 \mathrm{mmol})$ was added drop-wise while stirring. The reaction mixture was stirred for $2 \mathrm{~h}$ at room temperature and then the solvent volume was reduced by evaporation under reduced pressure. Addition of diethyl ether until precipitation reached completion and filtration afforded the solid intermediate salt. To a mixture of salt $(1 \mathrm{mmol})$, methanol $(5 \mathrm{~mL})$ and triethylamine $(1.5 \mathrm{mmol})$ was added 2chloromethyl benzothiazole (5) $(1 \mathrm{mmol})$ and the reaction mixture was stirred at room temperature for $24 \mathrm{~h}$. The methanol from the reaction mixture was evaporated under reduce pressure, EtOAc was added and the resulting solid was filtered off. The filtrate was washed with $\mathrm{H}_{2} \mathrm{O}(3 \times 15 \mathrm{~mL})$. The organic layers were collected, dried over $\mathrm{MgSO}_{4}$ and concentrated under reduce pressure to give the crude product. Purification by flash column chromatography gave the pure product.

\subsubsection{Benzo[d]thiazol-2-ylmethyl 4-(4-fluorobenzyl)piperazine-1-carbodithioate (47)}

Obtained in $45 \%$ yield as a yellow solid. Purification by flash column chromatography (DCM:MeOH 100:0 v/v, increasing to 90:10 v/v). ${ }^{1} \mathrm{H}-\mathrm{NMR}\left(\mathrm{CDCl}_{3}\right): 2.47-2.60\left(\mathrm{~m}, 4 \mathrm{H}, \mathrm{CH}_{2}-\right.$ piperazine), 3.49 (s, 2H, CH 2 ), 3.94 (bs, 2H, $\mathrm{CH}_{2}$-piperazine), 4.37 (bs, $2 \mathrm{H}, \mathrm{CH}_{2}$ piperazine), 5.11 (s, 2H, $\mathrm{CH}_{2}$ ), 7.00-7.04 (m, 2H, H-aromatic), 7.27-7.30 (m, 2H, H-aromatic), 7.34-7.41 (m, 1H, H-aromatic), 7.43-7.49 (m, 1H, H-aromatic), 7.80-7.86 (m, 1H, H-aromatic), 7.96-8.02 (m, 1H, H-aromatic). ${ }^{13} \mathrm{C}-\mathrm{NMR}\left(\mathrm{CDCl}_{3}\right) \delta: 39.0\left(\mathrm{CH}_{2}\right), 52.2\left(\mathrm{CH}_{2}\right), 61.6\left(\mathrm{CH}_{2}\right), 115.3(\mathrm{CH}, \mathrm{d}$, $\mathrm{J}=21 \mathrm{~Hz}), 121.6,122.9,125.2,125.8(\mathrm{CH}, \mathrm{C}$-aromatic), $130.6(\mathrm{CH}, \mathrm{d}, \mathrm{J}=7 \mathrm{~Hz}), 135.7,152.7$, 161.2, 163.2, 167.7, $194.4(\mathrm{C}) .{ }^{19} \mathrm{~F}-\mathrm{NMR}\left(\mathrm{CDCl}_{3}\right) \delta:-115.15(\mathrm{~s}, 1 \mathrm{~F})$. Melting point: $77-79^{\circ} \mathrm{C}$. UPLC-MS (Method C): Rt $1.75 \mathrm{~min}, \mathrm{MS}$ [ESI, m/z]: 418.2 [M+H]. Anal. Calcd for $\mathrm{C}_{20} \mathrm{H}_{20} \mathrm{FN}_{3} \mathrm{~S}_{3}:$ C, 57.53; H, 4.83; N, 10.06. Found: C, 57.60; H, 4.68; N, 9.92.

\subsubsection{Benzo $[d]$ thiazol-2-ylmethyl4-(3-(trifluoromethyl)benzyl) piperazine-1- carbodithioate (48)}

Obtained in 54\% yield as a yellow solid. Purification by flash column chromatography (DCM:MeOH 100:0 v/v, increasing to 90:10 v/v). ${ }^{1} \mathrm{H}-\mathrm{NMR}\left(\mathrm{CDCl}_{3}\right): 2.55$ (bs, 4H, $\mathrm{CH}_{2}-$ piperazine), 3.58 (s, 2H, CH ), 3.97 (bs, $2 \mathrm{H}, \mathrm{CH}_{2}$-piperazine), 4.38 (m, $2 \mathrm{H}, \mathrm{CH}_{2}$ piperazine), 
5.11 (s, 2H, $\mathrm{CH}_{2}$ ), 7.35-7.38 (m, 1H, H-aromatic), 7.44-7.48 (m, 2H, H-aromatic), 7.51-7.55 (m, 2H, H-aromatic), 7.59 (s, 1H, H-aromatic), 7.81-7.83 (m, 1H, H-aromatic), 7.97-7.99 (m, 1H, H-aromatic). ${ }^{13} \mathrm{C}-\mathrm{NMR}\left(\mathrm{CDCl}_{3}\right) \delta: 39.0\left(\mathrm{CH}_{2}\right), 52.4\left(\mathrm{CH}_{2}\right), 61.8\left(\mathrm{CH}_{2},\right), 121.6,122.9$, 124.4 (m), 125.2, 125.6 (m), 126.0, 128.9, $132.3(\mathrm{CH}), 123.1$ (m), 130.7 (C, q, J= $33 \mathrm{~Hz})$, 135.7, 152.7, 161.2, 167.6, $194.5(\mathrm{C}) .{ }^{19} \mathrm{~F}-\mathrm{NMR}\left(\mathrm{CDCl}_{3}\right) \delta$ : -62.55 (s, 3F). Melting point: $71-$ $73^{\circ} \mathrm{C}$. UPLC-MS (Method C): $\mathrm{R}_{\mathrm{t}} 2.02 \mathrm{~min}, \mathrm{MS}$ [ESI, m/z]: 468.1 [M+H]. Anal. Calcd for $\mathrm{C}_{21} \mathrm{H}_{20} \mathrm{~F}_{3} \mathrm{~N}_{3} \mathrm{~S}_{3}$ : C, 53.94; H, 4.31; N, 8.99. Found: C, 54.15; H, 4.46; N, 8.86.

\subsubsection{Benzo[d]thiazol-2-ylmethyl4-(4-(trifluoromethyl)benzyl) piperazine-1- carbodithioate (49)}

Obtained in 56\% yield as a white solid. Purification by co-precipitation from DCM $/ n$-hexane. ${ }^{1} \mathrm{H}-\mathrm{NMR}\left(\mathrm{CDCl}_{3}\right): 2.59$ (bs, 4H, $\mathrm{CH}_{2}$-piperazine), 3.63 (s, 2H, $\left.\mathrm{CH}_{2}\right), 4.00$ (bs, $2 \mathrm{H}, \mathrm{CH}_{2}$ piperazine), 4.42 (bs, 2H, $\mathrm{CH}_{2}$ piperazine), 5.15 (s, 2H, $\left.\mathrm{CH}_{2}\right), 7.39-7.42$ (m, 1H, H-aromatic), 7.48-7.51 (m, 3H, H-aromatic), 7.62-7.64 (m, 2H, H-aromatic), 7.85-7.87 (m, 1H, H-aromatic), 8.01-8.03 (m, 1H, H-aromatic). ${ }^{13} \mathrm{C}-\mathrm{NMR}\left(\mathrm{CDCl}_{3}\right)$ \&: $39.0\left(\mathrm{CH}_{2}\right), 52.4\left(\mathrm{CH}_{2}\right), 61.8\left(\mathrm{CH}_{2}\right)$, 121.6, 122.9, 125.2, 125.4 (m), 126.1, 128.4 (CH, q, J=130 Hz, C-aromatic), 131.8 (m), 135.7, 152.7, 161.2, 163.2, 167.7, $194.4(\mathrm{C}) .{ }^{19} \mathrm{~F}-\mathrm{NMR}\left(\mathrm{CDCl}_{3}\right) \delta$ : -63.00 (s, 3F). Melting point: 99$101^{\circ} \mathrm{C}$. UPLC-MS (Method C): $\mathrm{R}_{\mathrm{t}} 2.03 \mathrm{~min}, \mathrm{MS}$ [ESI, m/z]: 468.1 [M+H]. Anal. Calcd for $\mathrm{C}_{21} \mathrm{H}_{20} \mathrm{~F}_{3} \mathrm{~N}_{3} \mathrm{~S}_{3}:$ C, 53.94; H, 4.31; N, 8.99. Found: C, 53.77; H, 4.57; N, 8.83.

\subsubsection{Benzo $[d]$ thiazol-2-ylmethyl4-phenethylpiperazine-1-carbodithioate (50)}

Obtained in $41 \%$ yield as a white solid. Purification by co-precipitation from DCM $/ n$-hexane. ${ }^{1} \mathrm{H}-\mathrm{NMR}\left(\mathrm{CDCl}_{3}\right)$ : 2.62-2.70 (m, 6H, $\left.\mathrm{CH}_{2}\right), 2.85-2.82\left(\mathrm{~m}, 2 \mathrm{H}, \mathrm{CH}_{2}\right), 4.01$ (bs, $2 \mathrm{H}, \mathrm{CH}_{2}-$ piperazine), 4.42 (bs, 2H, $\mathrm{CH}_{2}$-piperazine), 5.15 (s, 2H, $\mathrm{CH}_{2}$ ), 7.21-7.25 (m, 3H, H-aromatic), 7.29-7.34 (m, 2H, H-aromatic), 7.37-7.41 (m, 1H, H-aromatic), 7.47-7.50 (m, 1H, H-aromatic), 7.84-7.86 (m, 1H, H-aromatic), 8.00-8.02 (m, 1H, H-aromatic). ${ }^{13} \mathrm{C}-\mathrm{NMR}\left(\mathrm{CDCl}_{3}\right) \delta: 33.1$ $\left(\mathrm{CH}_{2}\right), 39.0\left(\mathrm{CH}_{2}\right), 52.4\left(\mathrm{CH}_{2}\right), 59.6\left(\mathrm{CH}_{2}\right), 121.6,122.9,125.2,126.0,126.4,128.5,128.6$ (CH, C-aromatic), 135.7, 139.2, 152.7, 167.6, 194.5 (C). Melting point: 87-89 ${ }^{\circ} \mathrm{C}$. UPLC-MS (Method C): $\mathrm{R}_{\mathrm{t}} 1.70 \mathrm{~min}, \mathrm{MS}$ [ESI, m/z]: $414.2[\mathrm{M}+\mathrm{H}]$. Anal. Calcd for $\mathrm{C}_{21} \mathrm{H}_{23} \mathrm{~N}_{3} \mathrm{~S}_{3}: \mathrm{C}, 60.98$; H, 5.61; N, 10.16. Found: C, 60.75; H, 5.42; N, 10.28 .

\subsubsection{Benzo $[d]$ thiazol-2-ylmethyl 4-(phenylsulfonyl)piperazine-1-carbodithioate (51)}

Obtained in $40 \%$ yield as a white solid. The crude product precipitated out from the reaction mixture. Purification by co-precipitation from $\mathrm{DCM} / n$-hexane followed by flash column chromatography (DCM 100:0 v/v). ${ }^{1} \mathrm{H}-\mathrm{NMR}\left(\mathrm{CDCl}_{3}\right)$ : 3.14-3.18 (m, 4H, $\mathrm{CH}_{2}$-piperazine), 4.27 (bs, 4H, $\mathrm{CH}_{2}$-piperazine), 5.05 (s, 2H, $\mathrm{CH}_{2}$ ), 7.37-7.40 (m, 1H, H-aromatic), 7.45-7.49 (m, 1H, H-aromatic), 7.56-7.60 (m, 2H, H-aromatic), 7.64-7.68 (m, 1H, H-aromatic), 7.76-7.78 
(m, 2H, H-aromatic), 7.81-7.83 (m, 1H, H-aromatic), 7.97-7.99 (m, 1H, H-aromatic). ${ }^{13} \mathrm{C}-\mathrm{NMR}$ $\left(\mathrm{CDCl}_{3}\right)$ 8: $39.0\left(\mathrm{CH}_{2}\right), 45.5\left(\mathrm{CH}_{2}\right), 121.6,122.8,125.4,126.2,127.7,129.4,133.4(\mathrm{CH}, \mathrm{C}-$ aromatic), 135.2, 135.5, 152.4, 166.9, 195.5 (C). Melting point: 171-173 C. UPLC-MS (Method C): $\mathrm{R}_{\mathrm{t}} 2.03 \mathrm{~min}, \mathrm{MS}$ [ESI, m/z]: $450.1[\mathrm{M}+\mathrm{H}], 472.1$ [M+Na]. Anal. Calcd for $\mathrm{C}_{21} \mathrm{H}_{23} \mathrm{~N}_{3} \mathrm{~S}_{3}$ : C, 60.98; H, 5.61; N, 10.16. Found: C, 60.75; H, 5.42; N, 10.28.

\subsubsection{Benzo $[d]$ thiazol-2-ylmethyl4-benzoylpiperazine-1-carbodithioate (52)}

Obtained in $50 \%$ yield as a white solid. Purification by flash column chromatography ( $n$ hexane-EtOAc 100:0 v/v, increasing to 60:40 v/v). ${ }^{1} \mathrm{H}-\mathrm{NMR}\left(\mathrm{CDCl}_{3}\right): 3.31-4.57\left(\mathrm{~m}, 8 \mathrm{H}, \mathrm{CH}_{2}\right.$ piperazine), 5.11 (s, 2H, CH 2$), 7.36-7.39(\mathrm{~m}, 1 \mathrm{H}, \mathrm{H}$-aromatic), 7.41-7.48 (m, 6H, H-aromatic), 7.82-7.84 (m, 1H, H-aromatic), 7.98-8.00 (m, 1H, H-aromatic). ${ }^{13} \mathrm{C}-\mathrm{NMR}\left(\mathrm{CDCl}_{3}\right) \delta: 38.9$ $\left(\mathrm{CH}_{2}\right), 121.6,122.9,125.4,126.2,127.1,128.7,130.3(\mathrm{CH}), 134.7,135.5,152.5,167.3,170.7$, 195.4 (C). Melting point: $125-127^{\circ} \mathrm{C}$. UPLC-MS (Method C): $\mathrm{R}_{\mathrm{t}} 1.93 \mathrm{~min}, \mathrm{MS}$ [ESI, m/z]: $414.2[\mathrm{M}+\mathrm{H}], 436.2[\mathrm{M}+\mathrm{Na}]$. Anal. Calcd for $\mathrm{C}_{20} \mathrm{H}_{19} \mathrm{~N}_{3} \mathrm{OS}_{3}$ : C, 58.08; H, 4.63; N, 10.16 . Found: C, 57.91; H, 4.51; N, 10.38 .

\subsubsection{Benzo $[d]$ thiazol-2-ylmethyl4-phenylpiperazine-1-carbodithioate (53)}

Obtained in $48 \%$ yield as a white solid. Purification by co-precipitation from DCM $/ n$-hexane. ${ }^{1} \mathrm{H}-\mathrm{NMR}\left(\mathrm{CDCl}_{3}\right.$ ): 3.30 (bs, 4H, $\mathrm{CH}_{2}$-piperazine), 4.13 (bs, 2H, $\mathrm{CH}_{2}$-piperazine), 4.51 (bs, 2H, $\mathrm{CH}_{2}$-piperazine) $5.14\left(\mathrm{~s}, 2 \mathrm{H}, \mathrm{CH}_{2}\right), 6.91-6.94$ (m, 3H, H-aromatic), 7.27-7.32 (m, 2H, Haromatic), 7.35-7.39 (m, 1H, H-aromatic), 7.44-7.48 (m, 1H, H-aromatic), 7.82-7.84 (m, 1H, H-aromatic), 7.99-8.00 (m, 1H, H-aromatic). ${ }^{13} \mathrm{C}-\mathrm{NMR}\left(\mathrm{CDCl}_{3}\right) \delta: 38.9\left(\mathrm{CH}_{2}\right), 48.9\left(\mathrm{CH}_{2}\right)$, 116.4, 120.8, 121.6, 122.9, 125.3, 126.1, 128.45 (CH, C-aromatic), 135.7, 149.9, 152.6, 167.5, 194.7 (C). Melting point: 110-112 ${ }^{\circ} \mathrm{C}$. UPLC-MS (Method C): $\mathrm{R}_{\mathrm{t}} 2.18 \mathrm{~min}, \mathrm{MS}$ [ESI, m/z]: $386.2[\mathrm{M}+\mathrm{H}]$. Anal. Calcd for $\mathrm{C}_{19} \mathrm{H}_{19} \mathrm{~N}_{3} \mathrm{~S}_{3}$ : C, 59.19; H, 4.97; N, 10.90. Found: C, 59.34; H, $5.05 ; \mathrm{N}, 10.75$.

\subsection{Molecular modelling}

All molecular docking studies were performed on a Viglen Genie Intel ${ }^{\circledR}$ Core $^{\mathrm{TM}}$ i7-3770 vPro CPU@ 3.40 GHz x 8 running Ubuntu 18.04. Molecular Operating Environment (MOE) 2019.10 ${ }^{29}$ and Maestro (Schrödinger Release 2019-3) ${ }^{39}$ were used as molecular modelling software. The ZBD of M2-1 protein was downloaded from the PDB data bank (http://www.rcsb.org/; PDB code 6G0Y). ${ }^{20}$ The protein was pre-processed using the Schrödinger Protein Preparation Wizard by assigning bond orders, adding hydrogens and performing a restrained energy minimisation of the added hydrogens using the OPLS_2005 
force field. Ligand structures were built with MOE and then prepared using the Maestro LigPrep tool by energy minimising the structures (OPLS_2005 force filed), generating possible ionization states at $\mathrm{pH} 7 \pm 2$, generating tautomers and low-energy ring conformers. A $12 \AA$ docking grid (inner-box $10 \AA$ and outer-box $21 \AA$ ) was prepared using as centroid the cocrystallised $\mathrm{Zn}$ atom. Molecular docking studies were performed using Glide SP precision keeping the default parameters and setting 5 as number of output poses per input ligand to include in the solution. The output poses were saved as mol2 file. The docking results were visually inspected for their ability to bind the active site.

Molecular dynamics simulations were performed on Viglen Genie Intel®Xeon ${ }^{\circledR}$ CPU ES$2403 @ 1.80 \mathrm{GHz}$ x 8 (graphic card: GeForce GTX 1080 Ti) running Ubuntu 18.04, using the Desmond package for MD simulation: OPLS_2005 force field in explicit solvent, employing the TIP3 water model. The initial coordinates for the MD simulation were taken from the best docking experiment result for each single compound. A cubic water box was used for the solvation of the system, ensuring a buffer distance of approximately $8 \AA$ between each box side and the complex atoms. The system was neutralized adding 27 chlorine counter ions. The system was minimised and pre-equilibrated using the default relaxation routine implemented in Desmond. A 150 ns MD simulation was performed, during which the equation of motion were integrated using a 2 fs time step in the NPT ensemble, with temperature $(300 \mathrm{~K})$ and pressure $(1 \mathrm{~atm})$ constant. All other parameters were set using the Desmond default values. Data were collected every 10 ps (energy) and every 40 ps (trajectory). Each protein-ligand complex simulation was performed in triplicate, using every time a random seed as starting point. Visualisation of protein-ligand complex and MD trajectory analysis were carried out using Maestro. RMSD, secondary structure and protein-ligand interactions analyses were performed using the Simulation Event Analysis tool and the Simulation Interaction Diagram of Desmond. The $\Delta \mathrm{G}_{\text {binding }}$ values of the protein-ligand complex were calculated using the MM/GBSA method as implemented in the Prime module from Maestro using the default settings and the Maestro script termal_mmgbsa.py. Briefly, the script takes in the MD trajectory from the last $80 \mathrm{~ns}$ of simulation, splits it into individual frame snapshots (extracted every $0.400 \mathrm{~ns}$, for a total of 201 frames), and runs each one through MMGBSA (after deleting waters and separating the ligand from the receptor). For each single simulation, an average $\Delta \mathrm{G}_{\text {binding }}$ values for the $80 \mathrm{~ns}$ is calculated.

\subsection{Biological assays}




\subsubsection{Media, cells, virus and compounds}

DMEM (catalogue no. 41965-039), PBS (catalogue no. 14190-094) and non-essential amino acid solution (NEAA; catalogue no. 11140-035) were obtained from Thermo Fisher Scientific. FBS was obtained from Hyclone (catalogue no. SV30160.03) and heat inactivated at $56^{\circ} \mathrm{C}$ for 30min. HEp-2 cells, RSV-A Long strain and RSV-B Wash strain were obtained from ATCC. ALS-8112 was synthesized according to published procedures (purity $>98 \%$ ). ${ }^{40}$

\subsubsection{Virus and cells for in vitro standard antiviral assay}

HEp2 cells were seeded at $5 \times 10^{3}$ cells/well in a 96-well plate and were further cultured in DMEM (supplemented with $2 \%$ FBS and $1 \%$ NEAA) at $37^{\circ} \mathrm{C}$ and $5 \% \mathrm{CO}_{2}$. The day after, medium was replaced by a serial dilution (1:2) of the antiviral test compounds in the same medium and the cultures were infected with RSV-A Long strain or RVS-B wash strain at an moi of $0.01 \mathrm{CCID}_{50} /$ cell (where $\mathrm{CCID}_{50}$ represents the $50 \%$ cell culture infectious dose in HEp2 cells). After 5 days, the typical cytopathic effect (CPE) was scored microscopically in all wells, on a scale of $0-5$. The $\mathrm{EC}_{50}$ was calculated by logarithmic interpolation as the concentration of compound that resulted in a $50 \%$ protective effect against virus-induced CPE. Potential compound toxicity was evaluated in a similar set-up in treated, uninfected cultures where metabolic activity was quantified at day 5 by using the 3-(4,5-dimethylthiazol-2-yl)-5(3-carboxymethoxyphenyl)-2-(4-sulfophenyl)-2H-tetrazolium (MTS) readout. The $\mathrm{CC}_{50}$ was calculated by logarithmic interpolation as the concentration of compound that resulted in a $50 \%$ decrease in the MTS signal.

\section{Acknowledgements}

M.B. and S.F. were supported by the Sêr Cymru II programme which is part-funded by Cardiff University and the European Regional Development Fund through the Welsh Government.

\section{Appendix A. Supplementary data}

All experimental procedures and compound characterisation data for the reaction intermediates are reported and described in detail in the Supporting Information.

\section{References}

1- Borchers, A.T.; Chang, C.; Gershwin, M.E.; Gershwin, L.J. Respiratory syncytial virus- A comprehensive review. Clin. Rev. Allergy Immunol. 2013; 45: 331-379. 
2- Griffiths, C.; Drews, S.J.; Marchant, D.J. Respiratory syncytial virus: infection, detection, and new options for prevention and treatment. Clin. Microbiol. Rev. 2017; 30:277-319.

3- Wright, M.; Piedimonte, G. Respiratory syncytial virus prevention and therapy: past, present, and future. Pediatr. Pulmonol. 2011; 46:324-347.

4- Piedimonte, G. Perez, M.K. Alternative mechanisms for respiratory syncytial virus (RSV) infection and persistence: could RSV be transmitted through the placenta and persist into developing fetal lungs? Curr. Opin. Pharmacol. 2014; 16:82-88.

5- Xing, Y.; Proesmans, S. New therapies for acute RSV infections: where are we? Eur. J. Pediatr. 2019; 68:18-26.

6- Ventre, K.; Randolph, A. G. Ribavirin for respiratory syncytial virus infection of the lower respiratory tract in infants and young children. Cochrane Data. Syst. Rev. 2007; 24:CD000181.

7- Frogel, M.; Nerwen, C.; Cohen, A. et al. Prevention of hospitalization due to respiratory syncytial virus: results from the palivizumab outcomes registry. $J$. Perinatol. 2008; 28: 511-517.

8- Sun, Z.; Pan, Y.; Jiang, S.; Lu, L. Respiratory syncytial virus entry inhibitors targeting the F protein. Viruses 2013; 5:211-225.

9- Shahabi, A.; Peneva, D.; Incerti, D. et al. Assessing variation in the cost of palivizumab for respiratory syncytial virus prevention in preterm infants. PharmacoEconomics-Open 2017; 2:1-9.

10- Behzadi, M.A.; Leyva, V. H. Overview of current therapeutics and novel candidates against influenza, respiratory syncytial virus, and middle east respiratory syndrome coronavirus infections. Front. Microbiol. 2019; 10:1327.

11- Cockerill, G. S.; Good, J. A. D.; Mathews, N. State of the art in respiratory syncytial virus drug discovery and development. J. Med. Chem. 2019; 62:3206-3227.

12- Peret, T.C.; Hall, C.B.; Schnabel, J.A. et al. Circulation patterns of genetically distinct group A and B strains of human respiratory syncytial virus in a community. J. Ge. Virol. 1998; 79:2221-2229.

13- Sutherland, K.A.; Collins, P.L.; Peeples, M.E. Synergistic effects of gene-end signal mutations and the M2-1 protein on transcription termination by respiratory syncytial virus. Virology 2001; 288: 295-307. 
14- Tran, T.-L.; Castagné, N.; Dubosclard, V. et al. The respiratory syncytial virus M2-1 protein forms tetramers and interacts with RNA and $\mathrm{P}$ in a competitive manner. $J$. Virol. 2009, 83:6363-6374.

15- Hardy, R.; Wertz, G. The Cys3-His 1 motif of the respiratory syncytial virus M2-1 protein is essential for protein function. J. Virol. 2000; 74:5880-5885.

16- Cai, H.; Zhang, Y.; Ma, Y.; Sun, J.; Liang, X.; Li, J. Zinc binding activity of human metapneumovirus M2-1 protein is indispensable for viral replication and pathogenesis in vivo. J. Virol. 2015; 89:6391-6405.

17- Pannecouque, C.; Szafarowicz, B.; Volkova, N. et al. Inhibition of HIV-1 Replication by a Bis-Thiadiazolbenzene-1,2-Diamine That Chelates Zinc Ions from Retroviral Nucleocapsid Zinc Fingers. Antimicrob Agents Chemother. 2010; 54: $1461-1468$.

18- Boukhvalova, M.S.; Prince, G.A.; Blanco, J.C.G. Inactivation of respiratory syncytial virus by zinc finger reactive compounds. Virol. J. 2010; 7:1-10.

19- Tanner, S.J.; Ariza, A.; Richard, C. et al. Crystal Structure of the essential transcription antiterminator M2-1 protein of human respiratory syncytial virus and Implications of its phosphorylation. Proc.Natl.Acad.Sci.USA 2014; 111: 1580-1585.

20- Selvaraj, M.; Yegambaram, K.; Todd, E.J.A.A. et al. The structure of the human respiratory syncytial virus M2-1 protein bound to the interaction domain of the phosphoprotein P defines the orientation of the complex. MBio 2018; 9: e01554-18.

21- Cancellieri, M.; Bassetto, M.; Widjaja, I. et al. In silico structure-based design and synthesis of novel anti-RSV compounds. Antivir. Res. 2015; 122: 46-50.

22- Borate, H.B.; Maujan S.R.; Sawargave, S.P. et al. Fluconazole analogues containing 2H-1,4-benzothiazin-3(4H)-one or 2H-1,4-benzoxazin-3(4H)-one moieties, a novel class of anti-Candida agents. Bioorganic Med Chem Lett. 2010; 20:722-725.

23- Zuo, H.; Meng, L.; Ghate, M. et al. Microwave-assisted one-pot synthesis of benzo[b][1,4]oxazin-3(4H)-ones via Smiles rearrangement. Tetrahedron Lett. 2008; 49:3827-3830.

24- Peprah, K; Zhu, X.Y.; Eyunni, S.V.K.et al. Structure-activity relationship studies of SYA 013, a homopiperazine analog of haloperidol. Bioorganic Med Chem. 2012; 20:1671-1678.

25- Peterson, Q.P.; Hsu, D.C.; Goode, D.R. et al. Procaspase-3 activation as an anticancer strategy: Structure-activity relationship of procaspase-activating compound 1 
(PAC-1) and its cellular co- localization with caspase-3. J Med Chem. 2009; 52:5721-5731.

26- Biannic, B.; Bozell, J.J. Efficient cobalt-catalyzed oxidative conversion of lignin models to benzoquinones. Org Lett. 2013; 15:2730-2733.

27- Zhang, C.; Tan, C.; Zu, X. et al. Exploration of (S)-3-aminopyrrolidine as a potentially interesting scaffold for discovery of novel Abl and PI3K dual inhibitors. Eur J Med Chem. 2011; 46:1404-1414.

28- Henderson, B.J.; Carper, D.J.; González-Cestari, T.F. et al. Structure-activity relationship studies of sulfonylpiperazine analogues as novel negative allosteric modulators of human neuronal nicotinic receptors. J Med Chem. 2011; 55:86818692.

29- Bali, A.; Sharma, K.; Bhalla, A. et al. Synthesis, evaluation and computational studies on a series of acetophenone based 1-( aryloxypropyl )-4-( chloroaryl ) piperazines as potential atypical antipsychotics. Eur J Med Chem. 2010; 45:26562662.

30- Azizi, N.; Aryanasab, F.; Saidi, M.R. Straightforward and highly efficient catalystfree one-pot synthesis of dithiocarbamates under solvent-free conditions. Org Lett. 2006; 8:5275-5277.

31- Güzel, Ö.; Salman, A. Synthesis, antimycobacterial and antitumor activities of new (1,1-dioxido-3-oxo-1,2-benzisothiazol-2(3H)-yl)methyl N,N- disubstituted dithiocarbamate/O-alkyldithiocarbonate derivatives. Bioorganic Med Chem. 2006; 14:7804-7815.

32- Jangir. S.; Bala, V.; Lal, N. et al. A unique dithiocarbamate chemistry during design \& synthesis of novel sperm-immobilizing agents. Org Biomol Chem. 2014; 12:30903099.

33- Deval, J.; Hong, J.; Wang, G. et al. Molecular basis for the selective inhibition of respiratory syncytial virus RNA polymerase by 2'-fluoro-4'-chloromethyl-cytidine triphosphate. PLoS Pathog. 2015; 11: e1004995.

34- Gillis, E.P.; Eastman, K.J.; Hill, M.D. et al. Applications of fluorine in medicinal chemistry. J. Med. Chem. 2015; 58: 8315-8359.

35- Schrödinger Release 2019-3: Maestro, Schrödinger, LLC, New York, NY, 2019

36- Schrödinger Release 2019-3: Desmond Molecular Dynamics System, D. E. Shaw Research, New York, NY, 2019. Maestro-Desmond Interoperability Tools, Schrödinger, New York, NY, 2019. 
37- Adasme-Carreño, F.; Muñoz-Guiterrez, C.; Caballero, J. et al. Performance of the MM/GBSA scoring using a binding site hydrogen bond network-based frame selection: the protein kinase case. Phys. Chem. Chem. Phys. 2014; 16:14047-14058.

38- Schrödinger Release 2019-3: Prime, Schrödinger, LLC, New York, NY, 2019.

39- ULC, C. C. G. Molecular Operating Environment (MOE), 2019.10, 1010 Sherbooke St. West, Suite \#910, Montreal, QC, Canada, H3A 2R7, 2019.

40- Wang, G.; Deval, J.; Hong, J. et al. Discovery of 4'-chloromethyl-2'-deoxy-3',5'-diO-isobutyryl-2'-fluorocytidine (ALS-8176), a first-in-class RSV polymerase inhibitor for treatment of human respiratory syncytial virus infection. J. Med. Chem. 2015; 58: 1862-78. 